\title{
An empirical study on the relationship between customers' credit rating and their financial statements for loan assignment
}

\author{
Hassan Najafi ${ }^{\mathrm{a}^{*}}$ and Ahmad Ahmadkhani ${ }^{\mathrm{b}}$
}

${ }^{a}$ Department of accounting , Islamic Azad University, Hamedan Branch, Hamedan,Iran

${ }^{b}$ Sama technical vocational training college; Islamic Azad University;Zanjan Branch;Zanjan;Iran

\begin{tabular}{l}
\hline A R T I C L E I N F O \\
\hline Article history: \\
Received June 20, 2011 \\
Received in Revised form \\
August, 5, 2011 \\
Accepted 10 August 2011 \\
Available online \\
12 August 2011 \\
\hline Keywords: \\
Banking industry \\
Loan assignment \\
Customer rating \\
Financial transcript \\
Revenue management
\end{tabular}
A B S T R A C T

\begin{abstract}
One of the most important issues on revenue management in banking industries is the assignment of loan to customers. In fact, a big portion of banks' revenue is from loan assignment and choosing appropriate customers for loan assignment not only reduces the financial risk but also it can increase the revenue. In this study, we perform an empirical study to find out whether customers' financial statements could provide enough information about customers for loan assignment. The other objective of this study is to find out whether banks' officials could understand about the details of customers' financial statements. Finally, we want to find out whether there is any relationship between unpaid loans and customers' credit rating. The present study is executed on an Iranian bank by distributing a questionnaire analyzing the results. The results indicate that there are some strong evidence that financial statement could help bank official determine customers' credit rating. The survey also concludes that highly education and experienced employees are the best people for devoting best credit rating for customers.
\end{abstract}

\section{Introduction}

Loan assignment is one of the most important parts of revenue management in banking industry. Over two third of most banks' revenue is earned through assigning loans to their customers. Therefore, loan assignment plays an important role on financial strength of banks and there must be some regulations on properly ranking banks' customers (Curry et al., 2008). Customer ranking can be accomplished using different ways such as customers' personal characteristics, ethics or financial statements. Grunert et al. (2005) for instance used non-financial figures for assessing customers' ability to receive loan. During the past few years, there have been many methods and techniques developed to assess customers' financial abilities (Burak Emel et al., 2003; Thomas \& Wang , 2004; Angelini et al., 2008; Stefanescu et al., 2009; Tsai \& Chen, 2010; Bannierand \& Hirsch, 2010). Treacy and Carey (2000) investigated the internal rating systems presently in use for 50 largest US banking organizations using the diversity of current practice to illuminate the relationships between

\footnotetext{
* Corresponding author. Tel: +09193445021

E-mail addresses: rogiehniazy@yahoo.com (H. Najafi) 
uses of ratings, different options for rating system design, and the effectiveness of internal rating systems. Burak Emel et al. (2003) implemented data envelopment analysis for ranking customers who are seeking loans from banks. Carey and Hrycay (2001) proposed a method for credit risk models with rating data based on different parameters. They examined properties of the major techniques currently implemented to estimate average default probabilities by grade and presented some evidence on potential problems of bias, instability, and gaming. Jacobson et al. (2006) performed a study on internal risk rating systems (IRS) at large banks and investigated whether IRS produce consistent estimates of banks' loan portfolio credit risk. They found significant differences between the implied loss distributions of two banks with equal "regulatory" risk profiles; both expected losses and the credit loss rates at a wide range of loss distribution percentiles.

Curry et al. (2008) performed a study to study the short-term and long-term impact of bank supervision, measured using CAMEL composite and component ratings, on various categories of loan growth such as commercial and industrial loans, consumer loans, and real estate loans. They implemented dynamic loan growth equations at the state-level augmented by the inclusion of CAMEL ratings for all banks in the state, after controlling for banking and economic conditions. They performed their regressions for two distinct sub-periods of credit crunch and recovery and discovered that out of the three loan categories considered, business lending is the most sensitive to changes in CAMEL ratings in both the composite and the components, although the other loan categories also show some sensitivity. For the second period, they discovered little evidence that changes in CAMEL ratings, the composite or its components, had any systematic impact on loan growth for any of the loan categories considered.

Many people blamed the recent global turmoil on global market, started during the year of 2008 from real states market, for assigning loans to customers for no good reason. In fact, many people believe that the increase competition among bank industry changed banks' policy on credit ranking. Becker and Milbourn (2011) performed a study on how completion could impact credit rating and reported that increased competition from Fitch coincides with lower quality ratings from the incumbents. They explained that when rating levels went up, the correlation between ratings and market-implied yields fell, and the ability of ratings to predict default deteriorated.

In this paper, we present an empirical study to find out whether customers' financial statements could provide enough information about customers for loan assignment. The other objective of this study is to find out whether banks' officials could understand about the details of customers' financial statements. Finally, we want to find out whether there is any relationship between bad loans and customers' credit rating. The present study is executed on an Iranian bank and a questionnaire was distributed and the results are analyzed. This paper is organized as follows. We first present details of our questionnaire in section 2 and the results of our survey is explained in section 3. Finally, concluding remarks are given in section 4 to summarize the contribution of the paper.

\section{The proposed study}

In this study, we choose one of biggest Iranian bank named export development bank of Iran (EDBI). EDBI has been one of the most well known banks in the history of Iran's banking industry and it is considered as one of the well known banks. EDBI has 146 employee who are making loan assignment decisions and the present study use Kokran's formula to compute the size of sample as follows,

$$
n \geq \frac{N z^{2} p q}{(N-1) d^{2}+z^{2} p q}
$$

Where $n$ is the sample size, $N$ is the size of population, $d$ is an error term which is considered as 0.05 in this study, $z=1.96$ and $p=q=0.5$. Therefore, we need 106 expert to participate in our survey and 
we selected them from 19 different cities. From 106 people who participated in our survey, 16 were women and 89 were men representing 15 and 85 percent of women and men, respectively. Our survey indicated that they maintained good background knowledge. In fact, 13\% hold master degree, $80 \%$ had bachelor degree and only $7 \%$ maintained two years of college degree. They were mostly educated from related sciences such accounting, management, economy and banking studies. This means that the banks' experts are highly educated and we they also had good job experience. The survey results indicated that only $25 \%$ had less than 5 years of experience, $23 \%$ had between 5 to 10 years of experience, $46 \%$ had between 10 to 15 years of job experience and $6 \%$ had over 15 years of job experience. The following four hypothesis are investigated for the proposed study,

H1: There is a meaningful relationship between customers' credit rating and their financial statements.

H2: There is a meaningful relationship between customers' credit rating and the securities specifications.

H3: There is a meaningful relationship between customers' credit rating and familiarity of banks' experts with financial statements.

H4: There is a meaningful relationship between customers' credit rating and unpaid or delayed loans.

The first hypothesis consists of the following five questions,

1- There are sufficient information on customers' financial statements for assigning loans.

2- The financial information provided by customers are crystal clear.

3- The financial information provide enough evidence for assigning loans.

4- The customer's credit ranking is useful enough for assigning loans.

5- To give loans, we can rely on ratios derived from financial statements such as quick ratio, current ratio, working capital, etc.

The second hypothesis consists of the following five questions,

1- The loans are devoted proportion to securities received by banks.

2- The types of securities are based on the loans characteristics.

3- During the process of loan assignment, customers' past experiences are also considered in addition to their credit rating.

4- There is direct relationship between the amount of customers' equities and the amount of loans assigned.

5- There is logical relationship between loan and securities presented to bank.

The third hypothesis is also involved with the following questions,

1- All employee and experts who work for banks are trained for assigning loans to customers.

2- The knowledge of analyzing financial statements numbers and figures are used for loan assignments.

3- All employees have good background on analyzing financial statements numbers. 
4- A good analysis on financial statement could help reduce delayed loans.

5- Most bad loans belong to people who originally presented weak financial statements.

Finally, the last hypothesis consists of the following five questions,

1- There is strong relationship between customers' loan payment and their credit rating.

2- Customers with weak financial statements usually perform poorly on paying their loans' payments.

3- The unpaid loans belong to people with weak financial statements.

4- Using audited financial statements for loan assignment could reduce delayed or unpaid loans.

5- There is meaningful relationship between customers' turnover and unpaid loans.

\section{Results}

In order to examine each hypothesis we use a binomial test using the following formula,

$$
z=\frac{X-n p}{\frac{\sqrt{n p q}}{N}}
$$

where $n, p, q, X, N$ and $z$ are sample size, the chance of success, the chance of failure, the number of success, population size and normal statistical indicator, respectively. The answers of the questions are divided into two parts of completely agree and agree in one part and completely disagree and disagree in other part. We have counted the number of each part and calculated $p$ and $q$ based on these two numbers. To test the first hypothesis we choose a one side test of $H_{0}: p \leq 0.50$ against $H_{1}: p>0.50$. Table 1 summarizes the results of our survey.

\section{Table 1}

The details of the first hypothesis $H_{0}: p \leq 0.50$ against $\quad H_{1}: p>0.50$

\begin{tabular}{lcclll}
\hline Groups & Numbers & $p$ & Ratio & Significance level & Result \\
\hline For & 102 & 0.96 & \multirow{2}{*}{0.50} & \multirow{2}{*}{0.000} & \multirow{2}{*}{ Confirmed } \\
\hline Against & 4 & 0.04 & & & \\
\hline
\end{tabular}

As we can observe from the results of Table 1, the first hypothesis is strongly confirmed, which means the information of the financial statement could influence of customers' credit rating, significantly. The average scores associated with five questions in this part are $2.59,2.71,3.34,3.15$ and 3.21. According to the people who participated in our survey, the third question has the maximum impact on our hypothesis, which means that crystal clear financial statements could help more in making loan assignment decisions.

The second hypothesis is associated with the relationship between security type and credit rating. Table 2 shows details of our survey with $H_{0}: p \leq 0.50$ against $H_{1}: p>0.50$.

Table 2

The details of the second hypothesis $H_{0}: p \leq 0.50$ against $H_{1}: p>0.50$

\begin{tabular}{lcclll}
\hline Groups & Numbers & $p$ & Ratio & Significance level & Result \\
\hline For & 101 & 0.95 & \multirow{2}{*}{0.50} & \multirow{2}{*}{0.000} & \multirow{2}{*}{ Confirmed } \\
\hline Against & 5 & 0.05 & & & \\
\hline
\end{tabular}


Again, the null hypothesis is rejected and we can conclude that there is a strong relationship between the security type and financial figures. The average scores associated with five questions in this part are $2.93,2.91,2.69,3.02$ and 3.44. In this part, experts mostly believed that customers' past credits are more important than present financial statements. In other words, a person with good past credit history is more entitled to receive loan.

The third hypothesis concerns whether there is a relationship between bank employees' familiarities on financial statement and customers' credit rating and the results are summarized in Table 3.

Table 3

The details of the third hypothesis $H_{0}: p \leq 0.50$ against $H_{1}: p>0.50$

\begin{tabular}{lcccll}
\hline Groups & Numbers & $p$ & Ratio & Significance level & Result \\
\hline For & 98 & 0.92 & \multirow{2}{*}{0.50} & \multirow{2}{*}{0.000} & \multirow{2}{*}{ Confirmed } \\
\hline Against & 8 & 0.08 & & & \\
\hline
\end{tabular}

The hypothesis is confirmed, which means there is a positive relationship between employees' background knowledge and their decisions on credit rating. The average scores associated with five questions in this part are 3.38, 2.87, 3.16, 2.90 and 2.70. In this part, participants of our survey believed that experts with good training skills could make better loan assignment decisions and training plays an important role on this job.

Finally, the last question is on whether there is any relationship between customers' credit rating and unpaid loans and the results of our survey for this hypothesis is summarized in Table 4 as follows,

Table 4

The details of the fourth hypothesis $H_{0}: p \leq 0.50$ against $\quad H_{1}: p>0.50$

\begin{tabular}{lccccl}
\hline Groups & Numbers & $p$ & Ratio & Significance level & Result \\
\hline For & 99 & 0.93 & \multirow{2}{*}{0.50} & \multirow{2}{*}{0.000} & \multirow{2}{*}{ Confirmed } \\
\hline Against & 7 & 0.07 & & & \\
\hline
\end{tabular}

As we can clearly observe, the null hypothesis is rejected one more time indicating that there is positive relationship between a poor financial statement and unpaid loans. The average scores associated with five questions in this part are 3.30, 2.65, 2.99, 3.04 and 3.02. As we can observe from the people who took part in our survey, the first question was more important than other questions, which means there is a direct relationship between paying loans and customer's credit.

In summary, there are several ways to contribute the evaluation processes of loan assessments such as providing educational skills for training people with analyzing financial statements, keeping people's credit history as important criteria for evaluating loans' approval, etc.

\section{Conclusions}

In this paper, we have presented a survey to study the impact of different criteria on loan assessment. The proposed study of this paper has chosen one of the biggest Iranian banks and distributed a questionnaire consists of four sections among them. The survey confirmed that there was a positive relationship between customers' credit rating and their financial statements and people believed that crystal clear financial statements could help more in making loan assignment decisions. The second question of our survey confirmed the positive relationship between customers' credit and security type 
and the people who participated in our survey believed that people with good credit history must be more entitled to receive loan. The third part of our survey also confirmed a positive relationship between educational backgrounds of people who assess loan approval and credit rating they assign to customers. The last part of our survey confirmed that there is a positive relationship between credit rating and unpaid loans, which means people with bad credit may look to receive loan without paying them. The moral story is that there must be some organizations for keeping people's credit history similar to some organizations in North American countries.

\section{Acknowledgment}

The authors would like to express their special thanks to anonymous referees for their valuable comments on earlier version of this work.

\section{References}

Angelini, E., di Tollo, G., \& Roli, A. (2008). A neural network approach for credit risk evaluation. The Quarterly Review of Economics and Finance, 48(4), 733-755.

Bannierand, C.E., \& Hirsch, C.W. (2010). The economic function of credit rating agencies - What does the watchlist tell us?. Journal of Banking \& Finance, 34(12), 3037-3049.

Becker, B., \& Milbourn, T. (2011). How did increased competition affect credit ratings?. Journal of Financial Economics, 101(3), 493-514.

Burak Emel, A., Oral, M., Reisman, A., \& Yolalan, R. (2003). A credit scoring approach for the commercial banking sector. Socio-Economic Planning Sciences. 37(2), 103-123.

Curry, T.J., Fissel, G.S., \& Ramirez, C.D. (2008). The impact of bank supervision on loan growth. The North American Journal of Economics and Finance, 19(2), 113-134.

Carey, M., \& Hrycay, M. (2001). Parameterizing credit risk models with rating data. Journal of Banking \& Finance, 25(1), 197-270.

Grunert, J., Norden, L., \& Weber, M. (2005). The role of non-financial factors in internal credit ratings. Journal of Banking \& Finance, 29(2), 509-531.

Jacobson, T., Lindé, J., \& Roszbach, K. (2006). Internal ratings systems, implied credit risk and the consistency of banks' risk classification policies. Journal of Banking \& Finance, 30(7), 18991926.

Treacy, W. F., \& Carey, M. (2000). Credit risk rating systems at large US banks. Journal of Banking \& Finance, 24(1-2), 167-201.

Tsai, C.F., \& Chen, M.L. (2010). Credit rating by hybrid machine learning techniques. Applied Soft Computing, 10(2), 374-380.

Stefanescu, C., Tunaru, R., Turnbull, S. (2009).The credit rating process and estimation of transition probabilities: A Bayesian approach. Journal of Empirical Finance, 16(2), 216-234.

Thomas, H., \& Wang, Z. (2004). The integration of bank syndicated loan and junk bond markets. Journal of Banking \& Finance, 28(2), 299-329. 